\title{
The Origin of the Term Handicap in Games and Sports - History of a Concept
}

Authors' contribution:

A) conception and design of the study

B) acquisition of data

C) analysis and interpretation of data

D) manuscript preparation

E) obtaining funding

\section{Jørn Hansen}

University of Southern Denmark, Denmark

\begin{abstract}
Words and concepts may change in time, and this has certainly been the case with the term handicap. From the establishment of modern sports in the middle of the 19th century and up until the middle of the 20th century, handicap had an entirely different meaning within sports. Thus, handicap was understood as a disadvantage imposed on talented contestants to make the competition more equal in sports. Later the term handicap became much closer related to the concepts invalid and crippled than to concept originally employed within sports, With the gradual introduction of the welfare state measures to the political agenda the politicians in Denmark also started to take an interest in invalids and cripples and in 1925 the National Association of the Crippled and Maimed was founded. By the end of the 20 century the term crippled was seen by many as outdated and in 1988 the name was changed to the Danish Association for the Disabled (Dansk Handicap Forbund) and already in 1971 this organization helped to found The Danish Disabled Sports Association (Dansk Handicap Idræts-Forbund). The article tells the story of how the concept of handicap, which originally was an aim to provide equal opportunities, today has become a synonym for disability, while in the Paralympics and competitive disability sports, the original sports term handicap has been replaced by classification.

handicap, disability, invalid, crippled, Paralympics
\end{abstract}

Words and concepts, understood as an overall idea of features perceived as common and characteristic of a particular kind of things, creatures, facts, or phenomena, may change meaning over time. Within sports, the concept of amateur and professional is a well-known example of this, where an amateur was originally perceived as a term of honor for an athlete who practiced his sport out of love for the sport itself (the Latin word amare means "to love") and not for personal gain like the professional athlete. Today, the term amateur no longer has the same positive connotations, whereas it has become a term of honor to "adopt a professional approach" and stop behaving like a "lousy amateur".

Similarly, the idea about the features perceived as common and characteristic for the term handicap within sports has also changed over time. When the Danish Disabled Sports Association (Dansk Handicap Idræts-Forbund) was established in 1971 as an independent national association, it was initially the physically disabled who adapted existing sports and developed new sports, enabling them to be performed by persons with disabilities. Today, the Danish Disabled Sports Association, according to their homepage, 
organizes athletes with almost all kinds of disabilities, such as blind and visually impaired, hearing impaired, and physically and mentally challenged persons as well as persons with all kinds of physical disabilities. However, it seems that people with health problems and mental disorders are not included (Dansk Handicap Idræts-Forbund, 2015; Østerlund et al., 2014). Nevertheless, the handicap concept of the Danish Disabled Sports Association today is associated with an understanding of the term handicap as a:

"chronic physical or mental weakness that limits one's ability to function completely normally"

(Den Danske Ordbog, 2015).

And, yet, mental weakness is typically classified in more groups of people with disabilities. In the Danish Disabled Sports Association, only intellectually impaired people participate in so-called Special Olympics settings, and in official competition in this group, the IQ must not be higher than 75 . Braindamaged people are typically too weak to take part in disabled sport, and neither are those with mentally disorder because their disabilities are not necessarily chronic or permanent.

However, from the establishment of modern sports in the middle of the $19^{\text {th }}$ century and up until the middle of the $20^{\text {th }}$ century, the term handicap had an entirely different meaning within sports. Thus, handicap was understood as a disadvantage imposed on talented contestants to make the competition more even in sports such as horse riding and sailing (Den Danske Ordbog, 2014). This understanding of the term still prevails within golf and, to a certain extent, within horseracing.

\section{Sport and handicap rules}

Modern sports originated in Great Britain, from which it spread to the European continent and the rest of the globe. Accordingly, the term handicap is also of British origin, resulting from a synthesis of the words "hand in the cap". The term originates from a:

'swap game between three participants, in which the 'handicapper' determines how much money each of the other participants need to chip in to equalize the value of the objects for which the game is played" (Salomonsen, 1920, p. 811).

Since the end of the 17 century, making a bet at foot racing matches has been common in Great Britain.

"A Foot racing Match is to be Run, next Thursday upon North-Hall Common, the Space is six Miles, between Hugh, the Baker and Will, the Oats Stealer, for 60 Guinea's; the Latter gives 200 Yards, at starting, to the former" (Kloeren, 1985, p. 255).

During the $19^{\text {th }}$ century, the modern sport found its form and equal competition became an integrated part of the sports industry with an important view to betting and gambling (Polley, 2004).

Generally speaking, it was a question of creating the best conditions for betting in connection with betting matches,

"in which the aim is to provide equal opportunities for all participants by giving the stronger ones a disadvantage, and thus the weaker ones an advantage, compared to usual conditions" (Andersen et al., 1945, p. 500).

The person or committee deciding how this should be done is referred to as handicapper or advantage calculator and must have a thorough knowledge of the betting match, in addition to being completely impartial.

Depending on the sport, the handicapper would calculate the handicap in different ways. Horseracing was one of the first sports in which handicap rules were introduced. The rules were especially important, as there was a correlation between improvement of bloodstock and horseracing, making it very important to establish equal conditions for the participating horses and jockeys. With regard to horseracing, the regulation was made via weight. In the 1820s, the Duke of Augustenburg in Denmark organized several horse races following the British pattern at the village of Ketting not far from Augustenburg to demonstrate the 
correlation between good stud operation and good race horses (Hansen, 1989). It was said of the rules for organization of races that

"When a bet is made on a race with noble horses, their provenance must be conscientiously proved and, in relation to their age, the weight with which they are to run must be carefully calculated - as must the distance of the race. The jokey or rider sits, dressed as he would be for riding, on a steel weight holding saddle, blanket and girth, after which the entire weight is carefully measured. If he is too heavy, he usually removes as many of his clothes as he is willing to do without until the minimum overweight is reached. However, if he is too light, the missing weight must be made up for (...)" (Michelsen, 1830, p. 6).

Subsequently, handicap rules were introduced in show jumping, where the regulation was made by adjusting the height of the fences. With regard to harness racing, the regulation was made via a shift in the starting grid, creating a distance to the start line of 20,40,60, and 80 meters respectively depending on the strength (Nordisk Familjeboks Sportleksikon, 1940, p. 1082).

Up until the 1920s, handicap calculation was commonly used within the field of athletics in Denmark. In jumping and throwing, head start was given in centimeters. In short-distance running, it was given in meters, whereas head start was given in time at distances of 1,500 meters or more, when all athletes were to run the same distance. To ensure correct procedure, a number of handicap calculators were appointed at the annual meeting of representatives of the Danish Athletic Federation. (Andersen et al., 1945, p. 500).

Up until World War II and the time immediately afterward, each sport had its own unique way of calculating disability. Within badminton and tennis, handicap was usually awarded in advance by giving points to the weakest player or, in doubles, by giving the best players only one serve instead of two. In tennis, handicap could also take the form of giving individual players more serves (balls) than the higherranking player. In road cycling, head start was given in minutes, while in track cycling; head start was given in meters or points. With regard to kayaking, a preliminary race was held in which all kayakers started from the same position. In all subsequent races, handicap was awarded based on the rankings in the preliminary competition. In swimming, the person with the greatest handicap would start normally and the other competitors would start later based on the ranking made by the handicapper (Andersen et al., 1945, p. 500501).

To facilitate the work, handicap lists or handicap keys showing the strength of the players or athletes were compiled on a regular basis. Within certain sports, calculation of handicap was quite complex. In sailing races, handicap was calculated based on the time it took for a vessel to cover a nautical mile at different wind speeds, usually using earlier sailing races as a benchmark. Subsequently, the following method was employed:

"Along an abscissa axis with the wind speeds measured during sailing races, the sailing times are set out as ordinates and an even curve is drawn, which almost coincides with said ordinates. From this curve, the time per nautical mile is taken for the wind speeds corresponding to the ones used in the handicap tables (1-3, 3-5, 5-8 and above 8 meters per second)" (Andersen et al., 1945, p. 501).

Handicap calculation was thus a position of trust that could not be entrusted to all and sundry.

Within golf, where a handicap system is still used, a golfer's handicap in the first half of the $20^{\text {th }}$ century was calculated based on the Standard Scratch Score (SSS) of the course, each golfer being allowed a number of hits enabling him or her to "achieve a net marking equal to S.S.S. playing at his usual standard" (Andersen et al., 1945, p. 500). That method, despite a number of international adjustments, is quite similar to the method used to calculate handicap today (golf.dk). 


\section{From invalid or crippled to handicapped}

Golf and horseracing are two of the few sports in which the term handicap retains its original meaning. Within sports today, the term handicap is generally associated with disabled sports organizing persons with a "chronic physical or mental weakness that limits one's ability to function completely normally". Conceptually, this historical definition of the term handicap is much closer related to the concepts invalid and crippled than to the concept of handicap originally employed within sports. This is also the case with the earlier mention modification the concept of handicap employed by the Danish Disabled Sports Association today.

Invalid is derived from the Latin word invãlidus, which means powerless or weak. In the encyclopedia Salomonsens Konversationsleksikon (1920), invalid is defined as a:

"Soldier who during his service in either war or peace has been physically injured in that respect that he is no longer fit for military service. Depending on the implications of the physical injury, a distinction is made between different classes or degrees of invalid" (p. 467).

And invalidity is defined as a:

"Condition imposed on a person (civilian or military) due to an inflicted injury reducing his ability to function as a healthy person of similar age would otherwise be able to function. The concept may also be extended to cover such persons on whom a similar condition has been imposed due to ordinary illness" (p. 471).

In the same encyclopedia, the following definition of the concept crippled is found:

"Cripple denotes a person whose mobility is impaired, i.e. whose physical form deviates strongly from the norm, and whose opportunities of employment is thus greatly reduced either as a direct result of the deformity or indirectly, because his physical appearance is a hindrance for his ability to find usual employment. The terms overgrown, lame, maimed and deformed all fall under the overall concept of crippled. Originally, a distinction is made between crippled as a congenial state and crippled as an inflicted state, the discriminating factor being whether the person has been crippled before or after birth" (p. 521).

Contrary to an invalid, a cripple is thus a person whose mobility is reduced due to deformity or illness. Where invalidity is caused by an injury inflicted in war or in an accident, crippled as an inflicted state is thus usually caused by illness, with the exception of "so-called professional deformitie". These include what today would be defined as industrial diseases. At the same time, persons "on whom a similar condition has been imposed due to ordinary illness" are also included under the concept of invalidity, so in some ways, there was originally no clear distinction between being invalid and crippled.

With the gradual introduction of a number of social and welfare state measures to the political agenda in the late $19^{\text {th }}$ century and especially in the early $20^{\text {th }}$ century, the politicians in Denmark also started to take an interest in invalids and cripples. Despite the fact that the first proposal for the introduction of an invalidity benefit as part of a national insurance was set forth already in 1901, any benefits to invalids up until 1921 were granted under the ordinary poor law. Only in 1921 was an actual law on invalidity insurance introduced in Denmark. A law that later during the Social Democrat K. K. Steincke's major social reform in 1933 got included under the national insurance law (Betænkning nr. 228, 1959; Petersen, Petersen \& Christiansen, 2011).

The political measures also meant that a number of interest groups gathered their forces in relation to invalids and cripples. On November 18, 1925, the National Association of the Crippled and Maimed was founded with the aim of bringing together persons with physical disabilities and others interested in the work to improve the situation of those and to achieve equality with non-disabled persons. In 1948, the association changed its name to the National Association of Cripples. In the 1980s, the term cripple was seen by many as outdated, and at the conference in 1988, the name was changed to the Danish Association for the Disabled (Dansk Handicap Forbund). In some ways, this change of name came a little late, as the National Association 
of Cripples had already helped found the Danish Disabled Sports Association in 1971 (Lund, 2006; Dansk Handicap Forbund, 2015).

Even though National Association of Cripples was engaged in the founding of the Danish Disabled Sports Association, the latter found that the change of the name to the Danish Association for the Disabled meant a risk of confusion in the public and made objection to the name Danish Association for the Disabled. After a judgment first in the High Court and afterward in the Supreme Court on December 21, 1994, the objection was rejected. The Supreme Court decided that there was sufficient difference between the names of the two organizations (Blok, 1995).

In connection with the social reform in 1933, the Danish Association of the Blind, the Association of the Deaf-Mute of 1866, the Association of the Hard of Hearing, and the National Association of the Crippled and Maimed were asked to jointly appoint a representative to the invalidity insurance committee on business and employment conditions. The following year, this cooperation by the four associations led already to the foundation of the Joint Invalid Organisations, which became a powerful interest organization in relation to the state. In 1980, the Joint Invalid Organisations was thus behind the formation of the Danish Disability Council as an advisory body to the government.

The following year was proclaimed International Year of Disabled Persons by the UN, and the year of 1981 in many ways became crucial. The disability issue had previously been seen as a matter of charity, care, and compassion - all in all a purely social matter - but after 1981, it was made clear that it was an issue concerning equality and inclusion (Danske Handicaporganisationer, 2014).

Consequently, the term handicap became still more widely used, although the term invalid still formed part of the name of the Joint Invalid Organisations up until the end of 2007. By 2008, the organization changed the name to its current name of Disabled Peoples Organizations Denmark. An important reason for this was, among other things, given by the president of the Disabled Peoples Organisations Denmark in Odense, Birthe Malling:

"The old name comes from 1934, but today no one uses the word invalid. We are valid people with disabilities".

However, despite the fact that the term disabled has now become prevalent, "the word handicap is still used in everyday speech” (Fyens Stiftstidende, 2007; Danske Handicaporganisationer, 2014).

In this way, the term handicap became widely used as a concept that completely replaced the concepts of invalid and crippled. The present term handicap in Denmark is thus far removed from the original term used within sports in the $19^{\text {th }}$ century.

\section{Disabled and Paralympics}

One of the purposes of the Danish Disabled Sports Association is to promote exercise and elite sports for those who are disabled. Athletes from the Danish Disabled Sports Association got their first real international breakthrough in 1984 in New York at the Disabled Olympic Games, which had more or less systematically been associated with the ordinary Olympic Games since 1960.

The genesis of the Paralympics was the use of physical activity and sport in the act of rehabilitation of impaired individuals. Coincided with the opening of the 1948 Olympic Games in London, a doctor, Ludwig Guttmann, at Stoke Mandeville Hospital organized a sports event for his patients, who were all wheelchair users. At the Olympic Games in Seoul, the name was changed to the Paralympic Games, or simply the Paralympics, at the request of the International Olympic Committee. The term Paralympic refers to the Greek preposition para that means parallel or equal.

Critics find that, from 1960 to 1988, the Paralympics had more emphasis on participation than on high performance and that the Paralympics today caters to a less diverse impaired population than it did earlier. 
"It seems that the need for commercial success has had a detrimental effect on the most severely disabled competitors whose sporting opportunities have been increasingly reduced as the games have become a relatively large media spectacle" (Howe, 2012, p. 6; Paralympics, 2015a).

In both the Paralympic Games and the Danish Disabled Sports Association, the aim is to be seen as equal to able-bodied athletes, although - with few exceptions such as the South African runner Oscar Pistorius - the athletes neither can nor will compete under equal conditions. In accordance with the original term handicap within sports, the aim is to provide equal conditions in a competition but no longer by "handicapping" the best athletes.

Instead, disabled sports today in competitions, and especially in the Paralympics, use a classification system, IPC Classification, to ensure competition is fair and equal and to minimize the impact of impairments on the activity.

"All Paralympic sports have a system in place which ensures that winning is determined by skill, fitness, endurance, tactical ability and mental focus, the same factors that accounts for success in sport for able bodied athletes" (Paralympics, 2015b).

Today, there are ten eligible impairment types and the classification system is sport-specific because impairment affects the ability to perform in different sports to a different extent. Thus, in the Paralympics, the original term handicap has been replaced by classification

\section{REFERENCES}

Andersen, A. L., et al. (Eds). (1945). Dansk Sportsleksikon /Danish Sports Lexicon/. Copenhagen, Denmark: Standard Forlaget.

Betænkning nr. 228. (1959). Betcenkning om Invalideforsikringen afgivet af Invalideforsikringskommissionen af 1956. /Report on the invalidity insurance offered by Disability Insurance Commission of 1956/. Retrieved 12, 05, 2014 from http://www.statensnet.dk/betaenkninger/0201-0400/0228-1959/0228-1959_pdf/searchable_228-1959.pdf

Blok, P. (1995). Højesterets dom af 21. December 1994 om Foreningsnavneret /Supreme Court ruling of 21 December 1994 on Association law/. Ugeskrift for Retsvcesen U.1995B.418.

Danske Handicaporganisationer. (2014). Historien om konventionens tilblivelse /The story of the Convention genesis/. Retrieved 12, 04, 2014 from http://www.handicap.dk/politik/rettigheder/fn-konventionen/historien; http://www.handicap.dk/om-dh/historie/oversigt

Dansk Handicap Forbund. (2015). Retrieved 01, 05, 2015 from http://danskhandicapforbund.dk/fakta/historie

Dansk Handicap Idræts-Forbund. (2015). Retrieved 01, 05, 2015 from http://www.dhif.dk/FrontPage/?id=58

Den Danske Ordbog. (2015). Retrieved 01, 05, 2015 from http://ordnet.dk/ddo/ordbog?query=handicap

Fyens Stiftstidende. News Paper (31 December 2007).

Golf.dk. (2015). Retrieved 01, 05, 2015 from www.golf.dk/node/1050

Hansen, J. (1989). Sportens vej til Danmark - Hestevæddeløb /Sport route to Denmark - Horse Racing/. In E. Trangbæk (Ed.), Den engelske sports gennembrud i Norden /The breakthrough of English sports in the Nordic region/ (pp. 163172). Viborg: Dansk Idrætshistorisk Forening.

Howe, P. D. (2012). Disabled and sport. In J. Nauright \& C. Parrish (Eds.), Sports around the world: History, culture, and practice. Vol. 1. Santa Barbara, CA: ABC-Clio.

Kloeren, M. (1985). Sport und Rekord. Kultursoziologische Unetrsuchungen zum England des sechzehnten bis achtzehnten Jahrhunderts /Sports and record. Cultural Sociological Unetrsuchungen to England in the sixteenth to the eighteenth century/. Münster, Germany: Lit Verlag

Lund, J. (Ed.). (1994-2006). Den store danske Encyklopaedi bd. 4 /The great Danish Encyclopaedia Vol. $4^{\text {th }} /$. Copenhagen, Denmark: Danmarks Nationalleksikon.

Michelsen, G. (1830). Om Vaddeløbene ved Augustenborg i Aarene 1829 og om Stutteriet samme sted. IAbout Aries races at Augustenborg in the years 1829 and Stud same placel. Copenhagen, Denmark: Småskrifter.

Nordisk Familjeboks Sportlexicon. (1940). Uppslagsverk för Sport, Gymnastik och Friluftsliv /Encyclopedias for Sport, Exercise and Outdoor Recreation/. Stockholm, Norway: Nordisk Familjeboks Förlags.

Paralympics. (2015a). Retrieved 01, 05, 2015 from http://www.paralympic.org/the-ipc/history-of-the-movement 
Paralympics. (2015b). Retrieved 01, 05, 2015 from http://www.paralympic.org/classification

Petersen, J. H., Petersen, K., \& Christiansen, N. F. (Eds.). (2011). Dansk Velfcerdshistorie. Mellem skøn og ret, bd. II Perioden 1898-1933 /Danish Welfare history. Between discretion and right, Vol. II period 1898-1933/. Odense, Denmark: Syddansk Universitetsforlag.

Polley, M. (Ed.). (2004). The history of sport in Britain 1880-1914: Volume IV. Sport and Money. London, England: Routledge.

Salomonsens Konservationsleksikon. (1920). Anden Udgave 1915-1930 /Second Edition 1915-1930/. Copenhagen, Denmark: Schultz Forlagsboghandel.

Østerlund, K., Ryding, K., \& Jespersen, E. (2014). Idrcet, fritid og helbred for mennesker med funktionsnedsattelse ISports, leisure and health for people with disabilities/.Odense, Denmark: Idræt og Biomekanik, Syddansk Universitet.

AUTHOR'S ADDRESS:

Jørn Hansen

University of Southern Denmark

Institute of Sports Science and Clinical Biomechanics Campusvej 55

DK-5230,Odense M, Denmark

Email: jhansen@ health.sdu.dk 